\title{
A.Ü. SIYASAL BILGILER FAKÜLTESI KÜTÜPHANESI'NDEN DUYURU
}

Ưniversite eğitiminin araştırmaya yönelik olması, Ưniversite ve Fakülte kütüphanelerinin önemini artırmaktadır. Bu gerçekten yola çıkan Universite ve araştırma kütüphaneleri, içinde yer aldıkları Unniversite ya da Fakültede yapılan bilimsel araştırmaları destekleyecek, verilen eğitime yardımcı olacak yayınları sağlamakta ve kullanıcılara ulaştırmaktadir.

Ankara Unniversitesi Siyasal Bilgiler Fakültesi yüzyllı aşkın tarihiyle, toplumsal ve siyasal bilimlerin çeşitli dallarında öğretim görevi yapmaktadır. Fakülte kütüphanesi, fakültedeki araştırmaların, eğitimin gereksinim ve gelişmesine yanıt verebilmek için çalışmalarını sürdürmektedir.

Fakültemiz kütüphanesi salt öğretim görevlileri ve öğrencilere değil, fakülte dışından gelen araştırıcılara, kamu ya da özel kuruluşların görevlilerine de hizmet vermektedir. Bu kadar geniş kullanıcı kitlesi olan kütüphane, dermesinde yüzbini aşkın kitap, ellibin cilt civarında süreli yayın, 300 kişilik okuma salonu, periyodik salonu ve ödünç verme birimi ile hizmet vermeye çalışmaktadır.

Ancak dermedeki yayınların zenginliği kadar hatta daha da önemli olan konu dermenin güncelliğidir. Özellikle II. Dünya Savaşı scnrası dünyada görülen yayın patlaması nedeniyle kütüphaneler bütçe sıkıntısı çekmekte, kullanıcısına son gelişmeleri duyuran yayınları sağlaması zaman zaman olanaksızlaşmaktadır.

Fakültemiz kütüphanesi bu sıkıntıları yaşamakta, özellikle yurt dışı süreli yayın abonelerini sürdürebilmek için büyük uğraşlar vertnektedir. Bir yıllık yurt dışı süreli yayın abone bedeli, kütüphaneye ayrılan ödenegin tamamı ile ancak karşılanabilmektedir.

Ayrıca araştırıcıyı en kısa zamanda en doğru bilgiye ulaştırabilmek için kütuphanemizde yeni teknolojilerin kullanımı da artık zorunludur.

Tüm bu nedenlerle Fakültemis kütüphanesi, vẹrdiği hizmetleri çağdaşlaştırmak ve dermesini güncel tutabilmek amacıyla çeşitli girişimlerde bulunarak kütüpraneye önemli bağışlar sağlamıştır. 1989 yılı içinde kütüphanemize bağıs yapan kurumlar şunlardır: 
TURRTYE EMLAK BANKASI A.Ş.

TURKIYE İŞ BANKKASI A.Ş.

TURKIYE VAKIFI.AR BANKASI TA.O.

Ayrica Türkiye-ABD. Kültürel Mübadele Komisyonu (FULBRIGHT) Genel sekreterliği ile Fransız Büyükelçiliği kitap alımı olanağı sağlamıştır.

Tüm bu sevindirici yardımlara eklenen özel kir bağışla da Fakültemiz Kütüphanesine bilgisayar alınarak kütüiphane çalışmalarında otomasyona geçilmiştir. Kütüphanemizin bilgisayarı, Arthur ANDERSEN Muhasebe ve Müşavirlik LTD. Ş’઼I'nin Fakültemize yaptığı bağışla sağlanmıştir.

Söz konusu bağışlar, bağışı yapan kuruluşlamn eğitim ve öğretime gösterdiği ilginin değerli bir kanıtıdır. Bağışlar kütüphanemizin okuma salonunda yer alan onur panolam ve onur ilsteleri ile kullanicilarımiza duyurulmaktadır.

Kütüphanemiz bu tür bağış girişimlerini önümiuzdeki yıllarda da sürdürerek kullanıcılarına daha iyi hizmet vermeyi amaçlamaktadır. 